\title{
Does a Nearby Murder Affect Housing Prices and Rents? The Case of Sydney $^{*}$
}

\author{
Anastasia Klimova \\ Adrian D. Lee* \\ Economic Record, Accepted \\ Latest Draft: $16^{\text {th }}$ March 2014
}

\begin{abstract}
We measure the impact of murders on prices and rents of homes in Sydney. We find that housing prices fall by $3.9 \%$ for homes within 0.2 miles of the murder, in the year following the murder, and weaker results in the second year after a murder. We do not find any effects of murders on rents. Higher media coverage and being located closer to the murder (within 0.1 mile) have no additional effect on prices. Taken together, our findings suggest that proximity to a murder affects nearby property prices, particularly in the first year after the incident.
\end{abstract}

Keywords: Crime, murder, homicide, house prices, rent, hedonic model

JEL Classification: G14, K32, Q51, R2

\footnotetext{
* The paper has benefited from comments and suggestions by Susumu Imai, Meliyanni Johar, Jinu Kim, Daniel Melser, Gary Painter, Olena Stavrunova and conference participants at the 2012 American Real Estate and Urban Economics Association International Conference. We thank Australian Property Monitors for the provision of the house price and rental data and acknowledge funding from the UTS Business School Research Grant.

- Economics Discipline Group, University of Technology, Sydney, Sydney NSW 2000 Australia.

* Finance Discipline Group, University of Technology, Sydney, Sydney NSW 2000 Australia.
} 


\section{Introduction}

Homes stigmatized by traumatic events such as a murder or a suicide are well known to sell at deep discounts and to take longer to sell. However, there has been no research on whether a traumatic event near a home affects its price or rent. This question is pertinent for two reasons. Firstly, the magnitude of the spillover effect of the trauma onto the immediate area, as an unnatural death signals to existing and prospective homeowners of disamenities in the area, which may not have been so evident previously. Secondly, unnatural deaths, such as a murder, are usually only disclosed to the public by news media following police reports and so there would be search costs involved for the buyer to uncover such disamenities. Also, while in many US jurisdictions real estate agents are required to disclose stigmatized features of a particular home, it is not clear to what extent one needs to disclose nearby murders and other ill occurrences. Buyers and renters may therefore be unaware of the stigmatized features of a property.

This paper attempts to measure the effect of murders on housing prices and rents in Sydney, the largest and most populous city in Australia, from 2003 to 2010. In contrast to the US, Australia experienced an economic and housing boom throughout this period with no large decreases in prices during the global financial crisis in 2008. The murder rate during the data period was quite low, on average 1.31 victims per 100,000 in Sydney, and exhibited a downward trend. The low murder rate and reasonable geographic spread of murders across Sydney allow an analysis of the impact across very small regions and specific points in time without other confounding effects.

This paper contributes to a growing literature on house prices and the fear of crime. We follow in the same vein of literature on disamenity risks such as a sex offender moving into a neighbourhood (e.g. Linden and Rockoff (2008); Pope (2008); Wentland, Waller et al. 
(2013)) and the discovery of a methamphetamine laboratory (meth lab) (e.g. CongdonHohman (2012)). These papers find that prices fall between $4 \%$ to $10 \%$ after the impact of the disamenity (an arrival of a sex offender or a discovery of a meth lab). These papers avoid typical endogeneity issues with crime and house prices ${ }^{1}$ by assuming the arrival or discovery of a disamenity is random for a very small geographic region (e.g. within 0.25 to 0.3 miles from it). For example, Linden and Rockoff (2008) estimate individuals' valuation of living in close proximity to a convicted sex offender by exploiting both intertemporal and crosssectional variance in the presence of an offender, and Pope (2008) observes not only the arrivals of offenders in the neighbourhoods but their departures as well. All these studies find that the presence of offenders causes a $4 \%$ to $10 \%$ reduction in the sale price of homes within 0.1 miles of the disamenity. Unlike this paper, however, previous studies make use of databases publicly available from either county departments or the police, which makes search costs low for buyers.

This paper also contributes to a larger body of literature investigating the impact of crime on house prices spanning decades, starting from papers by Thaler (1978) and Hellman and Naroff (1979). A more recent paper by Pope and Pope (2012) examines the relationship between changes in crime rates and property prices during the nationwide decrease in crime in the USA in 1990s. They find a strong relationship between crime and property values during that time. However, the impact of the cost of crime on house prices is not uniform throughout the market (Lynch and Rasmussen (2001), Ihlanfeldt and Mayock (2010)) and often depends on the type of crime. When weighing the seriousness of offences by the cost of crime to victims instead of the customary measures of the number of index crimes, Lynch and Rasmussen (2001) find that the cost of crime has almost no impact on house prices overall; however, homes are highly discounted in high crime areas. By investigating the relationship

\footnotetext{
${ }^{1}$ Ihlanfeldt, K. and T. Mayock (2010) p. 162 provides a summary of the potential endogeneity issues.
} 
between different crime types and house prices, Gibbons (2004) finds that crimes in the criminal damage category (e.g. vandalism, graffiti) have a significant negative impact on prices, while burglaries have no measurable impact on prices. While most papers focus on a single type of crime, Ihlanfeldt and Mayock (2010) study the effect of various types of crime on housing prices and find that of their seven different categories of crime only robbery and aggravated assault crimes had a significant impact on housing values.

Moreover, this paper contributes to the limited literature on the relationship between crime and residential property rents. Some studies of the effect of crime on rents find the relationship to be negative. For example, Ozanne and Malpezzi (1985) find that crime decreased rents in Pittsburgh and Phoenix in 1974. In his study of rents, Rizzo (1979) estimated an elasticity of an overall crime measure with respect to rents of -0.24 in Chicago in 1970 (or -0.15 when controlling for the income, which he explained by low quality housing being confounded with high crime rates in its effect on rents) (p.18).

Another valuable contribution of this paper is the unique data set that we use to analyse the effect of murders on property prices. We collected a vast amount of information on murders in Sydney between 2003 and 2010. From the official statistics we obtained the number of murder victims by month and area and then manually matched each victim with details of each murder, using an array of sources ranging from news articles to police media releases and court decisions.

Using a merged database of murders, with housing prices and rents in Sydney, we find that housing prices within 0.2 miles and one year of a murder fall by $3.9 \%$. High media coverage and being closer (within 0.1 miles) to a murder have no additional effect on prices, suggesting that murders have no localized effect. We also find no effect on rents, and weaker results when using a longer, two-year window. Taken together, our findings suggest that 
proximity to a murder affects nearby housing prices, particularly in the first year after the incident.

This paper proceeds as follows: section 2 provides background on murders and house prices in Sydney; then we develop hypotheses in section 3, followed by a description of the data in section 4; section 5 describes the methodology, section 6 reports our results and section 7 concludes.

\section{Murders in Sydney}

The rate of murder in Sydney is similar to that of Australia as a whole and reasonably low in comparison to the world. Appendix A reports yearly intentional homicide rates per 100,000 people for Sydney, Australia, Canada, Japan, United Kingdom and the United States from 2003 to 2008. Statistics for Sydney are compiled from NSW Bureau of Crime Statistics and Research (BOCSAR) murder victim statistics and Australian Bureau of Statistics Sydney population statistics. Country murder rates are taken from the UN data website. ${ }^{2}$ Overall, all countries have experienced falling or stable murder rates over the period. Sydney has also experienced a reduction in murder rates from 1.62 per 100,000 in 2003 to 1.02 in 2008. On average, the murder rate in Sydney is 1.31 , which is second only to Japan in the sample of the countries. This is despite Sydney being the most populous and densely populated city in Australia, with about 5,849 people per square mile in 2009. The low murder rate and large size of Sydney, therefore, allow us to study house prices before and after the event of a murder in a specific location.

Murders in Sydney are often reported in the large city newspapers or local newspapers, due to their rarity and shocking nature for Sydneysiders. Since 2004, both state

\footnotetext{
${ }^{2}$ http://data.un.org/Data.aspx?d=UNODC\&f=tableCode\%3A1.
} 
legislation and case law $^{3}$ require real estate agents to disclose whether a murder has occurred in a house. The law was introduced after a real estate agent failed to disclose a triple murder that had occurred in a house, with the buyer only realising the home's history after paying a deposit. The law, however, does not require agents to provide information on nearby murders. There are even fewer disclosure requirements for rental agreements, suggesting that rental tenants may suffer even higher search costs for disamenities.

\section{Hypothesis Development}

In a market where homeowners and renters are fully informed of murders, there are two ways in which a murder may affect nearby housing prices and rents. Firstly, homes where a murder has been committed clearly sell at a discount and so arguably nearby homes might also be discounted due to the stigma of living near these homes. Secondly, a nearby murder may also be considered a disamenity as it brings psychological anxiety and stress to neighbours. For example, Sharkey (2010) finds that African-American children in Chicago neighbourhoods have statistically lower vocabulary and reading assessment scores if a murder occurs in their block group less than a week before the assessment task. While the findings of Sharkey (2010) are short-term, they nonetheless show that the effect of murder on nearby residents is non-trivial. Our first hypothesis is therefore:

H1: Homes closer to a murder location have greater price falls than those slightly further away.

Murders, however, are not always fully disclosed, and buyers and renters require much research to uncover such disamenities. Sellers, on the other hand, would have better

\footnotetext{
${ }^{3}$ See Property, Stock and Business Agents Act 2002 (NSW) s 52 and Hinton \& Ors v. Commissioner of Fair Trading, NSWADT, 2006.
} 
knowledge of a nearby murder through community word of mouth, closer attention to media about the local area and police doorknocking. It is possible that extensive media coverage can reduce such information asymmetry. However, a by-product of such coverage is a possible sensationalisation of the murder, increasing the fear of crime in the local area (e.g. Ditton and Duffy (1983), Smith (1984) and Williams and Dickinson (1993)). Such an increased fear of crime may depress prices more in the area than if the murder was unreported or only reported locally. This, therefore, provides us with our second hypothesis:

H2: Murders with high media coverage lead to greater price falls than those with low media coverage.

\section{Data}

We use two datasets in our analysis of the effects of murder on house prices and rent. The first source is the NSW BOCSAR recorded crime dataset. The data is available freely from the BOCSAR website ${ }^{4}$. The dataset is derived from police incident reports and recorded on the NSW Police Force's Computerised Operation Policing System (COPS). It provides monthly crime statistics including the offence type, number of each offence (or victims in the case of murder or manslaughter) in a Local Government Area (LGA). Each LGA covers many suburbs, with Sydney containing 38 LGAs. A map of the 38 LGAs of Sydney is found in Figure 1.

From the recorded crime dataset, we take the monthly number of murder victims in each Sydney LGA. We choose murder instead of manslaughter as a murder is more likely to be announced through news media due to its severity and infrequency. With the murder victims by month and LGA, we then manually match each victim with details of each murder

\footnotetext{
${ }^{4}$ http://www.bocsar.nsw.gov.au/lawlink/bocsar/ll_bocsar.nsf/pages/bocsar_research.
} 
through articles from the NSW Police media releases ${ }^{5}$, court decisions ${ }^{6}$ and local, city or national newspapers via Factiva and/or their web pages from 2005 to 2009 . We use this sample period as we require two years of sales data before and after a murder and we have house sales and rental data from 2003 to 2011. Using the sources of information mentioned above, we compiled data to add to the BOCSAR statistics, including information on the date when the murder occurred, and a suburb and a street where murder victim(s) were found. If the exact location is not found we look for information that can bring us closer to the location of a murder event. For example, a news article may state that a murder occurred at a home near a certain intersection or at a commercial venue. We then make use of past ownership records from the Australian Property Monitors web database (www.apmpropertydata.com.au) and if a photo is shown in a news article, use Google map's 'street view' function to locate the exact address. We then geocode the location if the exact address is known or use the middle of the street if we do not have the exact location of the murder.

Appendix B provides details on the number of murder victims reported by BOCSAR and those that we are able to identify and/or geocode accurately by year of murder from 2003 to $2010 .^{7}$ We define an accurately geocoded murder as if we have the exact location of the murder or if a 0.1 miles radius covers the entire street where the murder occurred. In total from 2003 to 2010, we were able to find articles related to 327 of the 386 victims and accurately geocode 273 of the 386 murder victims reported by BOCSAR or almost $71 \%$. Our success at geocoding locations ranges from $62 \%$ of murders in 2004 to $80 \%$ of murders in 2009. This compares reasonably to Linden and Rockoff (2008) and Pope (2008) who match

\footnotetext{
${ }^{5} \mathrm{http}$ //www.police.nsw.gov.au/news/media_release_archives. Additional media releases are found using the Internet Archive website (http://www.archive.org/web/web.php) which captures the website at various points in time. Police media releases are also released through the Australian Associated Press (AAP).

${ }^{6} \mathrm{http}: / / w w w . a u s t l i i . e d u . a u$ and mainly decisions from the Supreme Court of New South Wales or the Supreme Court of New South Wales - Court of Criminal Appeal.

${ }^{7}$ While we only investigate murders from 2005 to 2009, we collect murders from 2003 to 2004 and 2010 to ensure the effects we find are not driven by murders prior to or after our sample period.
} 
$87 \%$ and $85 \%$ of sex offenders to an address in their datasets respectively. Of the 54 victims which we find articles for but could not accurately geocode, 47 was because of a lack of information in articles and seven were murder charges where the body was found elsewhere or not found at all. In all we analyse 175 unique murder locations from 2005 to 2009 .

Figure 2 plots the location of each murder within suburbs across LGAs. Murders cluster within Inner Sydney although for a majority of murders there is a reasonable geographical spread.

Table 1 reports summary statistics for the number of newspaper articles during the month after a murder in Panel A; a cause of death and a number of media articles in Panel B, and a location of the murder and a number of media articles in Panel C.

We find that most murders that we classify as having location data are reported in at least one newspaper with only 24 murders not having the location of the murder reported (See Table 1 Panel A). The Daily Telegraph also reports more murders than the Sydney Morning Herald consistent with tabloids reporting more on crime than broadsheets as Williams and Dickinson (1993) find.

The most common murder is a stabbing, accounting for $42.5 \%$ of murders followed by shootings at around $22 \%$. Perhaps due to its unusual nature, shootings also attract more media articles (mean of 3.69 articles per shooting murder) in comparison to stabbings (mean of 2.22) (See Table 1 Panel B). Finally, data shows that a home (house, apartment or other housing type) is the most common place for a murder representing $57 \%$ of murders. Street murders make up just over $21 \%$ while other locations such as commercial venues, recreational areas and other public places make up the remainder. Murders at public places such as parks, petrol stations, pubs and shopping malls also attract more newspaper articles on average than homes except for apartments where the mean number of articles is 4.03 (See Table 1 Panel C). 
Our second data source is from Australian Property Monitors (APM) which contains house sales and rental listings for the Sydney metropolitan area. The sales data contains the sales price and contract date from 2003 to 2011 while the rental listings come from a major internet listing service and contain the advertised weekly rental price and listing dates from 2003 to 2011. Both datasets also record characteristics of the homes including the property type (home or unit/condominium), the number of bedrooms and bathrooms, the size of the house $^{8}$ and whether the home has more than one parking spot. The data also contains an extensive list of 'additional' housing characteristics which include the types of rooms that the home has (e.g. balcony, separate dining, family room, sunroom, rumpus room, etc.); home comforts (e.g. air conditioning, heating, sauna, spa, pool, etc.) and views (e.g. water, harbour, ocean, district views etc.). Appendix C details the list of housing characteristics' variables that we use. For rental listings, we use the last advertised rental price of the property. We also filter out home sales prices and rents which have incomplete data. Prices and rents are also standardised to 2011 dollars using the consumer price index as per the methodology of Linden and Rockoff (2008).

We then match murder locations to sales and rental properties which occur within 0.3 miles radius of a murder location and one year before or after the murder. The use of 0.3 miles is the same boundary that Linden and Rockoff (2008) and Pope (2008) use for sex offender locations. Linden and Rockoff (2008) p.1106 state that their choice of 0.3 miles is based on the Louisiana law requiring sex offenders to inform all neighbours living within this distance from their home of their presence. As there is no such a law for murders, in Section 6.1 we consider the feasibility of using different distances.

Table 2 reports average housing characteristics for our housing sales data in Panel A and rental listings in Panel B. Column 1 of both Panels reports for not within 0.3 miles of a

\footnotetext{
${ }^{8}$ Unfortunately, the floor space of each unit is not provided.
} 
murder location and column 2 reports for homes within 0.3 miles of a murder location. As can be seen, on average, areas near murders have fewer houses and properties in those areas have fewer bedrooms, bathrooms, less parking, and sell at lower prices. Our findings are consistent with the literature on crime and house prices which finds that criminal activity tends to occur in cheaper neighbourhoods (e.g. Ihlanfeldt and Mayock (2010); CongdonHohman (2012)). While this may suggest an endogeneity problem between housing prices and rents with murders, we hope to overcome this by assuming murders are random within the 0.3 mile region of a murder and by comparing homes within 0.1 and 0.2 miles of the murder to homes between 0.2 and 0.3 miles away as we describe below.

\section{Methodology}

In order to test whether murders affect house prices, we apply the 'difference-indifference' hedonic model methodology that Linden and Rockoff (2008) and Pope (2008) use. The basis of the difference-in-difference approach is that homes near the murder are similar in characteristics to homes slightly further away from the murder.

Following Linden and Rockoff (2008) in the first stage, we compare whether there are any statistical differences in housing prices and rents for homes within 0.1 or 0.2 miles from a murder (the treatment groups) and between 0.2 and 0.3 miles (the control group) from the murder and one year prior to the murder. For the difference-in-difference test to work, prices and rents of homes within 0.1 or 0.2 miles of a murder must not be statistically different from those of homes slightly further away, between 0.2 and 0.3 miles away ${ }^{9}$. Statistical difference would suggest that our control variables cannot adequately account for spatial heterogeneity within murder locations due to some unobservable variables. For example, if murders tended to occur in known crime hotspots, this may make prices lower in the 0.1 mile radius despite

\footnotetext{
${ }^{9}$ The use of miles instead of metres is by convention in difference-in-difference studies for housing prices. 0.3 , 0.2 and 0.1 miles is approximately 483, 322 and 161 metres, respectively.
} 
controlling for all known housing characteristics. The test will also reveal whether wider (or narrower) samples may be chosen due to the degree of hetereogeneity in the control and treatment groups.

Formally, we apply the following regression for all homes within 0.3 miles of a murder and one year prior to the murder which is similar to equation 1 from Linden and Rockoff (2008) except for the inclusion of a 0.2 mile dummy variable. We include a 0.2 mile dummy variable following Pope (2008) to test whether there is an effect for slightly further distances from the murder. The regression we use is:

$$
\log \left(p_{i r t}\right)=\alpha_{t}+\pi_{1} D_{i r t}^{1 / 10}+\pi_{2} D_{i r t}^{2 / 10}+\varepsilon_{i r t},
$$

where $i, r, t$ subscript for the home, murder area and contract date respectively. $\log \left(p_{i r t}\right)$ is the $\log$ price or rent of a home. $\alpha_{t}$ is the intercept with year fixed effects. We also substitute the dependent variable with a dummy variable of 1 for whether the home is a house (or 0 otherwise), size of houses (in 1,000 square feet), number of bedrooms, number of bathrooms and a dummy variable of 1 for whether the home has multiple parking spots. $D_{\text {irt }}^{1 / 10}$ is a dummy variable with a value of 1 if a home is within 0.1 miles from a murder and 0 otherwise. $D_{\text {irt }}^{2 / 10}$ is a dummy variable with a value of 1 if a home is between 0.1 and 0.2 miles from a murder and 0 otherwise. Standard errors clustered ${ }^{10}$ by the location of the murder are used following Linden and Rockoff (2008). We also apply the regression to our rental listings database.

In the second stage, we formally test whether murders affect the prices and rents of homes by applying the following regression to homes within 0.2 miles and homes within 0.3 miles of a murder:

\footnotetext{
10 These are White, H. (1980) standard errors adjusted to account for possible within cluster correlation. See Petersen, M. A. (2009) for more detail on clustered standard errors.
} 


$$
\begin{aligned}
\log \left(p_{i r t}\right)=\alpha_{r t} & +\sum_{c=1}^{C} b_{r t c} z_{i r t c}+c_{r t} t_{i m e_{r t}}+d_{r t} t i m e_{r t}^{2}+\omega_{0} D_{i r t}^{3 / 10}+\pi_{0} D_{i r t}^{2 / 10}+\gamma_{0} D_{i r t}^{1 / 10} \\
& +\left(\omega_{1} D_{i r t}^{3 / 10}+\pi_{1} D_{i r t}^{2 / 10}+\gamma_{1} D_{\text {irt }}^{1 / 10}\right) \text { after }_{\text {irt }}+\varepsilon_{i r t}
\end{aligned}
$$

where $\alpha_{r t}$ are the year/quarter and murder area fixed effects, $z_{\text {irtc }}$ are our $c$ housing characteristic measures. time is a factor to control for linear time trends specific to the murder area while time $e^{2}$ takes into account quadratic time trends. $D_{\text {irt }}^{3 / 10}$ is a dummy variable with the value of 1 if a home is between 0.2 and 0.3 miles from a murder and one year before

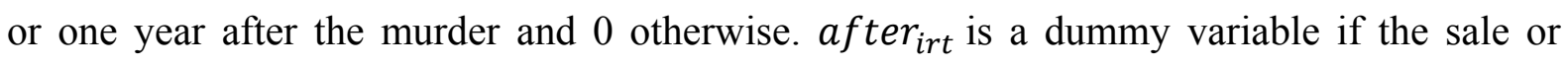
rental listing occurs between one month to one year after the murder. We exclude one month after the murder to allow for information about the murder to have spread to buyers and sellers. When we extend our analysis to the full sample of sales or rental listings, we use suburb fixed effects instead of murder area fixed effects and suburb linear time trend.

For rental listings, we substitute the dependent variable with log of the weekly rental price. If murders had an impact on house prices or rents, the coefficient $\pi_{1}$ or $\gamma_{1}$ would be negative and statistically significant.

We also extend the basic difference-in-difference model to test our hypothesis on media coverage. To test the high media hypothesis, we create an interaction variable media $a_{r t}$ with a value of 1 if there are more than two articles in the two major Sydney newspapers, The Sydney Morning Herald and The Daily Telegraph in the first month following the murder which reveal the location of the murder, and 0 otherwise. We use more than two articles to define a murder with high media coverage, as the median number of articles for all murders is two. We interact media with the $D_{i r t}^{1 / 10}, D_{i r t}^{2 / 10}$ and $D_{i r t}^{3 / 10}$ and After $r_{i t}$ dummy variables. If the coefficients for $D_{\text {irt }}^{1 / 10} \times a$ after $_{i t} \times$ media $_{r t}, D_{\text {irt }}^{2 / 10} \times a$ fter $_{i t} \times$ media $_{r t}$ and $D_{\text {irt }}^{3 / 10} \times a$ fter $_{i t} \times$ media $_{r t}$ 
are negative and statistically significant then this suggests that houses near murders that had high media exposure had larger price falls for homes within 0.1 miles, between 0.1 and 0.2 miles and between 0.2 and 0.3 miles respectively, than those that did not.

Following Pope (2008), an area where a murder occurred is defined within 0.3 miles of only one murder and either one year before or after it. The homes within 0.3 miles of more than one murder are excluded from the murder location samples. The purpose of this classification is to ensure the homes studied are not affected by other murders which may lead to ambiguous results. For example, if a home sale occurs before one murder and also occurs immediately after another one then it is difficult to assign it to either a treatment (after a murder) or non-treatment group (before a murder or between 0.2 and 0.3 miles of a murder).

We also only analyse the effect of murders which locations were geocoded with accuracy as per Appendix B. We make use of accurate locations so that we can also investigate whether being very close to the murder location (e.g. next to the murder or a few doors away) affects housing prices and rents.

Table 3 reports the extent to which these filters affect our sample. We find that the majority of sales $(13,218$ or above $91 \%)$ and rental listings $(25,196$ or above $89 \%)$ within at least one murder incident are affected by only one murder. As such the majority of homes within 0.3 miles and one year before or after were exposed to only one murder.

\section{Results}

\subsection{Homogeneity of Homes within 0.3 Miles of a Murder}

For our difference-in-difference hedonic model to produce reliable results, homes within 0.1 or 0.2 miles must be reasonably homogenous compared with homes between 0.2 and 0.3 miles from a murder. 
Table 4 Panel A estimates equation 1 using home sales across housing characteristics from columns 1 to 6 and a sample of sales one year before a murder and within 0.3 miles of a murder. The results show that there is a statistically significant difference in housing characteristics of the treatment groups to the control groups, with the treatment group homes being cheaper and smaller. ${ }^{11}$ For example, sale prices of homes within 0.1 miles of a murder are $6.7 \%$ lower than those of homes between 0.2 and 0.3 miles. Moreover, within 0.1 miles there are $9.8 \%$ fewer houses, and they are on average 742 square feet smaller, with fewer bedrooms, bathrooms and parking spaces than those further away. Similar results are found for homes between 0.1 and 0.2 miles of a murder.

The hetereogeneity between areas suggests that home between 0.2 and 0.3 miles potentially do not make a good control group as there may be some unobserved characteristics that we cannot control for. This also means that we are unable to use homes further than 0.3 miles (e.g. homes between 0.3 and 0.5 miles) due to the hetereogeneity of areas. Consequently, we consider using homes closer to the murder, between 0.1 and 0.2 miles as a control (Table 4 Panel A columns 7 to 12) and find there is no statistical difference between the two samples. As such, in our second stage regressions, we consider using both the 0.3 mile and 0.2 miles samples for robustness. For our rental sample (Table 4 Panel B), we find little statistical difference between the control and treatment groups.

\subsection{Effect of Nearby Murders on Housing Prices and Rents}

This section reports our baseline estimates of equation 2 for sales and rental listings. Noting potential omitted variables issues as found in the above section, we use different specifications of equation 2. As shown in Table 5, we find evidence of house prices within a

\footnotetext{
${ }^{11}$ Using fixed effects for areas close to a murder does not reduce the statistical differences in characteristics that we find.
} 
0.2 mile radius of and up to one year after a murder falling by between $3.8 \%$ to $5.0 \%$, although no change in rents was observed.

On our basic model for housing prices, using the full sample in column 1 (similar to the specification of Linden and Rockoff (2008)'s Table 3 column 4) ${ }^{12}$, we find no statistical difference in prices for homes within 0.1 miles of a murder or between 0.1 and 0.2 miles to those between 0.2 and 0.3 miles away, as evident by the coefficients for 'Within 0.1 miles of murder' and 'Between 0.1 and 0.2 miles of murder' variables. This suggests that the inclusion of housing characteristics, fixed effects and time trends helps explain the price differences that we found in Table 4 Panel A. For our treatment samples, the coefficients of 'Within 0.1 miles of murder $\times$ after' and 'Between 0.1 and 0.2 miles of murder $\times$ after' variables are negative but not statistically significant, suggesting that prices of houses closest to a murder do not differ from those only slightly further away.

In column 2, where we constrain the sample to only sales one year before or after a murder and within 0.3 miles of a murder, we find the coefficients of 'Between 0.1 and 0.2 miles of murder $\times$ after' and 'Within 0.1 miles of murder $\times$ after' variables are -0.033 and 0.032 respectively and statistically significant.

To correctly estimate the percentage impact of a dummy variable on the level of the dependent variable in semilogarithmic regression equations, we follow Kennedy's approach ${ }^{13}$ (Goldberger (1968), Halvorsen and Palmquist (1980), Kennedy (1981)). The approximate unbiased estimator of the percentage change in price or rent due to change in our dummy variables is given by $\hat{p}=100\left(\exp \left\{\widehat{c}-\frac{1}{2} \widehat{V}(\widehat{c})\right\}-1\right)$ (Kennedy (1981)). Applying this

\footnotetext{
${ }^{12} \mathrm{We}$ only use suburb time trends and not suburb quadratic time trends for the full sample due to computational constraints.

${ }^{13}$ van Garderen and Shah (2002) derive an exact unbiased estimator, and after applying to teacher earnings, they find that 'Kennedy's estimates are practically indistinguishable from the exact unbiased ones" (p. 153). They explain that the estimates are expected to be close. Therefore, we choose Kennedy's approach in our study.
} 
formula, we find that housing prices after a murder fall by about $3.9 \%$. The $3.9 \%$ is an economically significant amount and is comparable to the fall in housing prices caused by proximity of sex offenders as in Linden and Rockoff (2008) (4.1\%) and Pope (2008) (2.3\%), except the affected area in latter studies is only within 0.1 miles. If we consider that a home one year prior and within 0.2 miles of a murder was worth ${ }^{14}$ about $\exp (13.13) \approx \$ 504,000$, then the loss from a negative effect of a nearby murder is about $\$ 19,600$ (USD $\$ 15,700^{15}$ ) per home. As such, the fall in dollar terms from a murder is more than twice as large as that estimated by Linden and Rockoff (2008), of USD\$5,500 for sex offenders moving into Mecklenberg County. If we make a further conservative estimate that there are about 60 homes within 0.2 miles of a murder, then each murder causes about $\$ 1,176,000$ in price falls.

In column 3, where we further constrain the sample to only homes within 0.2 miles, thereby ensuring homes are homogenous in the control and treatment areas, we find statistically significant and larger estimates of the coefficients of -0.037 and -0.042 respectively. Our findings suggest that using only sample of houses that were located closer to a murder reduces noise in our estimates, consistent with Linden and Rockoff (2008)'s results that are more statistically significant when using their 0.3 mile sample.

In order to test whether distance from a murder location affects pricing, column 4 uses a variable for the linear distance from the murder for sales within 0.1 miles of the murder, following Linden and Rockoff (2008)'s Table 3 column 6 methodology. The variable is scaled such that 0.1 miles $=1$. The coefficient for this variable 'Dist $\leq 0.1$ miles $\times$ after' is statistically insignificant, suggesting that prices of homes closer to the murder area do not fall

\footnotetext{
${ }^{14}$ Using the intercept coefficient estimate for Table 4 Panel A column 7 for the within 0.2 mile sample as the average log price.

${ }^{15}$ Using an average monthly AUD/USD rate of 0.80 across our sample period.
} 
more after the murder than those further away. This is consistent with the findings in columns 2 and 3 where both 0.2 and 0.1 mile dummy variables have similar coefficients.

Our rental results in columns 5 to 8 show no statistical significance for the 'after' coefficients, suggesting that murders have no effect on rental prices.

\subsection{Reconciliation of Full Sample and Murder Area Results}

Our results in section 6.2 and Table 5 for full sample versus 0.3 and 0.2 mile samples appear inconsistent prima facie as the coefficient of the variables of the full sample while being negative are not statistically different from zero. It therefore appears that we have picked the 0.3 and 0.2 miles since we have statistically significant results. ${ }^{16}$

A possible reason for these results is that we do not use a reasonable hedonic model for our regressions. We have used all variables at our disposal though there is a chance that we have overfitted the model which might have increased noise in our coefficient estimates. As such we estimate various hedonic models and report selection criteria to test whether our full model is the best fit for our samples. We report our results in Appendix D. Appendix D Panel A reports several models using the full sample starting with Model 1 that uses the least number of independent variables (only beds, baths, multiple parking, area size, street type dummies, housing type dummies which are common hedonic pricing variables used in the literature). The final Model 4 in Panel A includes all variables that we use in our baseline results. All our selection criteria adjusted $\mathrm{R}^{2}$, Akaike information criteria (AIC), Bayesian information criteria (BIC) and predicted residual sums of squares (PRESS) show that Model 4 is superior indicating we have used the best possible model in our baseline regressions. Appendix D Panel B and Panel C report results for the 0.3 mile and 0.2 mile sample respectively which show that while adjusted $\mathrm{R}^{2}$ is highest for Model 4 , Model 3 (without

\footnotetext{
${ }^{16}$ We thank the referee for this helpful suggestion.
} 
additional housing characteristics) has the lowest score for AIC, BIC and PRESS. In unreported results, we re-estimate our Table 5 baseline results without the additional housing characteristics and find qualitatively similar results. As such it does not appear the poor fit of our model is the reason for the inconsistent results.

Another possible reason for the lack of statistical significance is as Linden and Rockoff (2008) p.1,117 note when using full sample analysis that there 'is the assumption that the relationship between housing characteristics and prices outside of the offender areas are valuable in estimating the relationship between characteristics and prices within the offender areas.' They then go on to use only offender areas to estimate their results. Indeed CongdonHohman (2013)'s baseline results in Table 4 for meth labs also find negative insignificant result for the full sample and negative and statistically significant results for the within area results. He reasons that this is in part due to differences in hedonic valuations within the full sample and the within area results. As such, a simple method of reconciling our full sample and within area results is therefore to use murder area dummies to control for differences in characteristics in the full sample results.

Appendix E reports our results for full sample regressions using murder area fixed effects. Areas not within our murder areas are placed in their own area. Column 1 reports results with murder area fixed effects and murder area quadratic and linear time trends and finds the coefficient for 'Within 0.1 miles murder $\times$ after' variable is negative and statistically significant. Column 2 removes murder area quadratic time trends and shows similar results. These results therefore provide evidence that adjusting for differences in hedonic valuations between the entire sample and murder areas helps reduce the noise in our estimates. In columns 3 and 4 , when we include suburb fixed effects ${ }^{17}$ the coefficients for 'Between 0.1

\footnotetext{
${ }^{17}$ Unfortunately we were unable to further include suburb are linear or quadratic time trends as it was too computationally intensive.
} 
and 0.2 miles of murder $\times$ after" variables are negative and statistically significant and comparable to our 0.3 and 0.2 mile results. The above analysis demonstrates that the lack of significant results in our baseline full sample model is due to an inability to control for differences in hedonic valuation in murder areas rather than an inconsistency of results.

\subsection{The Effect of Media Coverage}

This section tests the effect of media coverage of murders by including an interaction effect for high media coverage to the baseline model. Table 6 reports our results for house prices (columns 1 to 3 ) and rents (columns 4 to 6 ). We find no evidence of highly publicised murders resulting in larger price falls. We find however that in areas where a murder has been heavily publicised there is a reduction in the severity of price falls in comparison to areas where a murder has had little or no publicity.

For house prices (Table 6 columns 1 to 3 ) for the different models we find the 'after' coefficients without high media interaction all to be negative and generally statistically significant for the different distances, consistent with the results in the previous section. The 'after' coefficients with high media interaction however are all positive although not statistically significant except for the 'Between 0.1 and 0.2 miles of high media murder $\times$ after' for the full sample estimate in Table 6 column 1 with a coefficient of 0.043 . This suggests that homes between 0.1 and 0.2 miles of a murder with high media coverage experience only a slightly higher drop in price of about $0.5 \%$ after the murder ${ }^{18}$.

For rents, we find the 'after' coefficients without media interaction are not statistically significant, consistent with the results in Table 5. Similar to house prices, the 'after' coefficients with media interaction are all positive and generally not statistically significant.

\footnotetext{
${ }^{18}$ To get this result, the estimated coefficients were adjusted following Kennedy (1981).
} 
Our results run counter to our expectation that high media coverage of murders reduce information asymmetry between buyers and sellers which results in the murder information being priced in. A potential explanation is that murders with high media coverage may result in greater police effort to catch the assailant and/or reduce crime in the immediate area and thereby increase the value of the area. In our results that are not report here, we run a logistic regression with the dependent variable being whether the murder had a high media coverage or not and independent variables with dummy variables for whether the victim was bashed, shot or stabbed; a dummy variable for whether the murder was gang-related; a dummy variable for whether there were multiple victims in the murder; and a dummy variable for whether the murder occurred inside a residence. Coefficients' estimates from this regression show that there is a statistically significant $96 \%$ chance of a multiple victim murder being a high media murder and only a $40 \%$ chance of a high media murder being in a residence. Hence, high media murders tend to also be more serious in nature (i.e. many victims and/or in a public place) and therefore, greater police effort is expected to solve the murder.

\subsection{Robustness Checks}

In this section we employ several robustness checks to investigate the veracity of our baseline results. Firstly, we stratify the sample by past LGA assault rates for each murder area. Secondly, we test whether the results are a result of price trends by using false murder dates one year prior to a murder and whether using a longer window of two years before and after a murder affects our results.

\subsubsection{Stratifying by Past Assault Rate}

In this section we test whether the assault rate of a murder area's LGA strengthens or weakens the effect of murders on house prices. The reasoning is that in an area where the assault rate is high, it would also be expected that the murder rate is high, as some assaults 
result in murder. Indeed Ihlanfeldt and Mayock (2010) find a correlation of $69 \%$ between murder and assault rate (crimes per acre). Also, in analysing the relationship between housing prices and violent crime, Tita, Petras and Greenbaum (2006) use the murder rate as an instrumental variable for violent crime and find that it is a justified instrument. As such we would expect that a murder in a LGA with a low assault rate would have a greater impact on nearby house prices than those areas with high assault rates given the lack of anticipation.

We test the above hypotheses by stratifying our murder locations into three equal groups based on five year average annual assault rate per capita for their LGAs. The annual rate per capita for a LGA is calculated as the yearly number of assaults from the BOCSAR recorded crime dataset divided by the LGA's population ${ }^{19}$ for the same year.

We report our results stratified by assault rate in Table 7 for prices in Panel A and rental listings in Panel B. For brevity, we only report it for the within 0.3 mile sample although we find qualitatively similar results using the entire sample and for the 0.2 mile sample. For housing prices in Table 7 Panel A, we find that for the low assault rate areas (in column 1) the coefficient for 'Between 0.2 and 0.3 miles of murder $\times$ after' is -0.039 and statistically significant while the coefficients are insignificant for the medium and high assault areas in columns 2 and 3. This is consistent with low assault areas being more impacted by a murder although we cannot prove causality of a murder affecting house prices as our variables of interests, 'Between 0.1 and 0.2 miles of murder $\times$ after' and 'Within 0.1 miles murder $\times$ after' remain statistically insignificant with stratification. One exception is for the medium assault areas where the coefficient for 'Between 0.1 and 0.2 miles of murder $\times$ after' is -0.024 and statistically significant. We find no effect of murders on rents when

\footnotetext{
${ }^{19}$ LGA yearly population statistics are obtained from the Australian Bureau of Statistics (ABS) website ' 3218.0 - Regional Population Growth, Australia'.
} 
stratifying by assault rate as shown in Table 7 Panel B. Overall, we do not find a pattern between the effect of a murder on house prices or rents and the assault rate.

\subsubsection{Falsification Tests using One Year Prior Murder Dates}

Following Linden and Rockoff (2008) we test whether our findings that housing prices falling within 0.3 miles of and after a murder may be driven by trends in prices prior to the murder. As such we repeat our analysis except for using false murder dates that are one year prior to the actual murder. We report our findings in Table 8 . For housing prices in columns 1 and 2 we find no statistically significant trends. This provides further support that the price falls we find are due to the murders and not a negative price trend in the area. For rental prices in columns 3 and 4 we also find no statistically significant trend.

\subsubsection{The Effect of Nearby Murders on Housing Prices and Rents Two Years After}

In this section we use an extended time frame of two years before and after the murder to test whether the effect of a murder extends further than a year. We report our results in Table 9. We find no statistically significant falls in prices for the 0.3 sample (column 1 ) or rents (columns 3 and 4) after the murder. However, for prices in the 0.2 sample in column 2 the 'Within 0.1 miles murder $\times$ after' coefficient is statistically significant with a value of 0.029 . This suggests that there is some evidence of the effect of a murder on prices extending beyond one year.

\section{Conclusion}

Murder is the worst form of violent crime and has an enormous impact on people related to the victims and on the neighbourhood in general. Our study attempts to measure the impact of murders on house prices and rents of nearby homes by using the time and spatial sparseness of murders in Sydney. We find evidence that the prices of homes within 0.2 miles of a murder fall by about $3.9 \%$ one year after the murder. Homes slightly closer, within 0.1 
miles, have similar falls. However, we find no evidence that murders with higher media coverage have a greater impact on house prices compared to those with low media coverage. Using false murder dates of one year prior, we find that the fall is not due to declining price trends. However, the effect is short-lived as we find only some difference in housing prices using a two-year window. We find no effect of murders on rents. Taken together, our findings suggest that proximity to a murder affects nearby housing prices, particularly in the first year after the incident; however greater media coverage of a murder does not worsen the fall in property prices. 


\section{References}

Congdon-Hohman, J. M. (2012). "The lasting effects of crime: The relationship of discovered methamphetamine laboratories and home values." Regional Science and Urban Economics.

Ditton, J. and J. Duffy (1983). "Bias in the newspaper reporting of crime news." British Journal of Criminology 23(2): 159-163.

Gibbons, S. (2004). "The Costs of Urban Property Crime." The Economic Journal 114(499): F441-F463.

Goldberger, A.S. (1968). "The interpretation and estimation of Cobb-Doulas Functions." Econometrica 35: 464-472.

Halvorsen, R. and Palmquist, R. (1980). "The interpretation of dummy variables in semilogarithmic equations." American Economic Review 70: 474-475.

Hellman, D. A. and J. L. Naroff (1979). "The impact of crime on urban residential property values." Urban Studies 16(1): 105-112.

Ihlanfeldt, K. and T. Mayock (2010). "Panel data estimates of the effects of different types of crime on housing prices." Regional Science and Urban Economics 40(2): 161-172.

Kennedy, P.E. (1981). "Estimation with correctly interpreted dummy variables in semilogarithmic equations." American Economic Review 71(4): 801.

Linden, L. and J. E. Rockoff (2008). "Estimates of the impact of crime risk on property values from Megan's Laws." American Economic Review 98(3): 1103-1127.

Lynch, A. K. and D. W. Rasmussen (2001). "Measuring the impact of crime on house prices." Applied Economics 33(15): 1981-1989.

Ozanne, L. and S. Malpezzi (1985). "The efficacy of hedonic estimation with the annual housing survey. Evidence from the demand experiment." Journal of Economic and Social Measurement 13(2): 153-172.

Petersen, M. A. (2009). "Estimating Standard Errors in Finance Panel Data Sets: Comparing Approaches." Review of Financial Studies 22(1): 435-480.

Pope, D. G. and J. C. Pope (2012). "Crime and property values: Evidence from the 1990's crime drop." Regional Science and Urban Economics 42: 177-188.

Pope, J. C. (2008). "Fear of crime and housing prices: Household reactions to sex offender registries." Journal of Urban Economics 64(3): 601-614.

Rizzo, M. J. (1979). "The cost of crime to victims: An empirical analysis." Journal of Legal Studies 8(1): 177-205.

Sharkey, P. (2010). "The acute effect of local homicides on children's cognitive performance." Proceedings of the National Academy of Sciences 107(26): 1173311738.

Smith, S. J. (1984). "Crime in the News." British Journal of Criminology 24(3): 289-295.

Thaler, R. (1978). "A note on the value of crime control: evidence from the property market." Journal of Urban Economics 5(1): 137-145.

Tita, G., T. Petras, et al. (2006). "Crime and Residential Choice: A Neighborhood Level Analysis of the Impact of Crime on Housing Prices." Journal of Quantitative Criminology 22(4): 299-317.

van Garderen, K.J. and Shah, C. (2002). "Exact interpretation of dummy variables in semilogarithmic equations." Econometrics Journal 5: 149-159.

Wentland, S., B. Waller, et al. (2013). "Estimating the Effect of Crime Risk on Property Values and Time on Market: Evidence from Megan's Law in Virginia." Real Estate Economics, forthcoming. 
White, H. (1980). "A heteroskedasticity-consistent covariance matrix estimator and a direct test for heteroskedasticity." Econometrica: Journal of the Econometric Society: 817838.

Williams, P. and J. Dickinson (1993). "Fear of crime: read all about it? The relationship between newspaper crime reporting and fear of crime." British Journal of Criminology 33(1): 33-56. 
Figure 1

Sydney Metropolitan Area and its 38 Local Government Areas

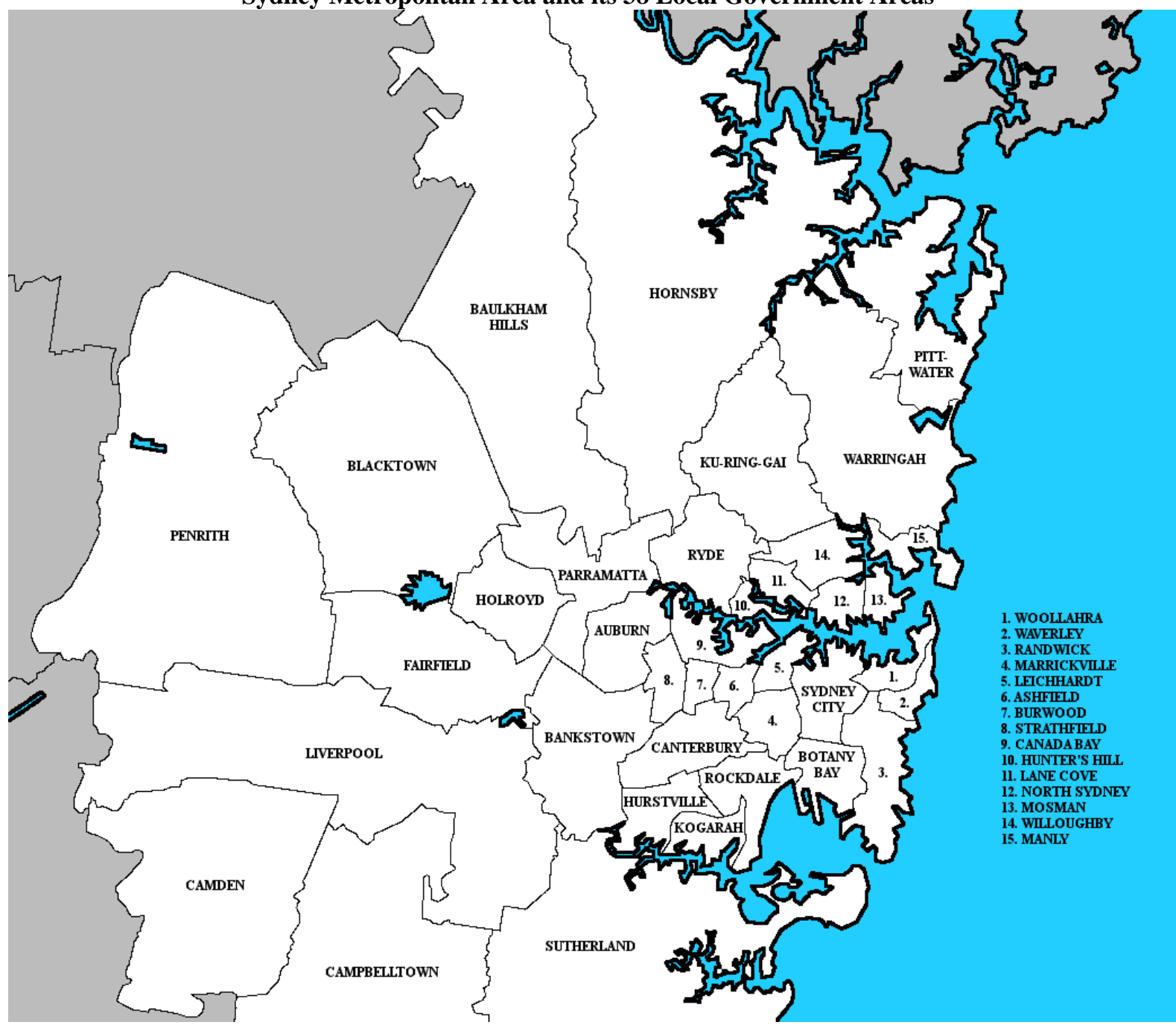

Source: http://en.wikipedia.org/wiki/File:Sydney_councils.png. 
Figure 2

Murder Locations across Sydney 2005-2009

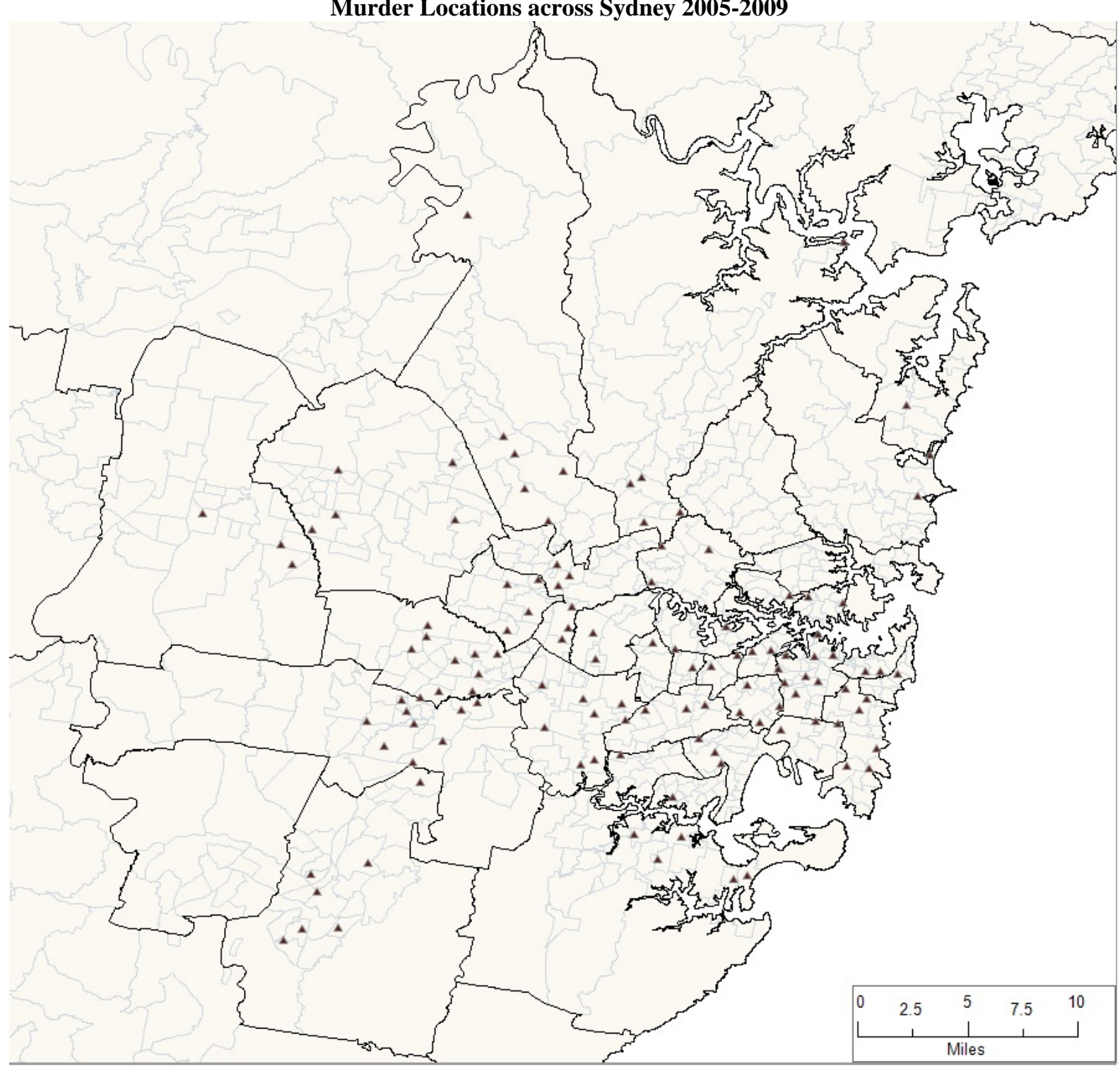

Notes: Triangles represent the location of each of the 160 murder incidents. Bold lines represent local government area borders while thin lines represent suburb borders. 1 mile is approximately 1,609 metres. 
Table 1

Murder and Media Summary Statistics

Panel A. Murder Incident Count by Newspaper Articles One Month After Murder Murder incident count by articles in month after murder

\begin{tabular}{|c|c|c|c|c|c|c|c|}
\hline Newspaper & No articles & 1 & 2 & 4 & $>5$ & \multirow{2}{*}{$\begin{array}{c}>5 \text { articles } \\
8\end{array}$} & Total murders \\
\hline Daily Telegraph & 26 & 51 & 24 & 14 & 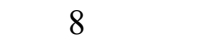 & & 160 \\
\hline Sydney Morning Herald & 93 & 44 & 12 & 2 & 1 & 2 & 160 \\
\hline Both & 24 & 40 & 21 & 17 & 13 & 20 & 160 \\
\hline \multicolumn{8}{|c|}{ Panel B. Murder Victim Cause of Death } \\
\hline Cause of death & & Count & Count $(\%)$ & \multicolumn{2}{|r|}{ Mean articles } & \multicolumn{2}{|c|}{ Median articles } \\
\hline Stabbed & & 68 & 42.50 & \multicolumn{2}{|r|}{2.22} & \multicolumn{2}{|l|}{1.5} \\
\hline Shot & & 35 & 21.88 & \multicolumn{2}{|r|}{3.69} & \multicolumn{2}{|l|}{3} \\
\hline Bashed & & 15 & 9.38 & \multicolumn{2}{|r|}{3.20} & \multicolumn{2}{|c|}{3} \\
\hline Asphyxiation & & 14 & 8.75 & \multicolumn{2}{|r|}{3.57} & \multicolumn{2}{|l|}{3} \\
\hline Blunt Force & & 13 & 8.13 & \multicolumn{2}{|r|}{2.77} & \multicolumn{2}{|l|}{2} \\
\hline Fall & & 6 & 3.75 & \multicolumn{2}{|r|}{2.67} & \multicolumn{2}{|l|}{2} \\
\hline Unknown & & 4 & 2.50 & \multicolumn{2}{|r|}{1.00} & \multicolumn{2}{|c|}{1} \\
\hline Burnt & & 3 & 1.88 & \multicolumn{2}{|r|}{2.33} & 3 & \\
\hline Poisoned & & 1 & 0.63 & & 5.00 & 5 & \\
\hline Vehicular & & 1 & 0.63 & & 4.00 & 4 & \\
\hline Total & & 160 & 100.00 & & 2.81 & 2 & \\
\hline Panel C. Location of Mu & ler Incident & & & & & & \\
\hline Location & & Count & Count (\%) & & Mean articles & $\mathrm{Mec}$ & an articles \\
\hline House (single-family deta & ed home) & 53 & 33.13 & & 2.85 & 2 & \\
\hline Sidewalk/Street & & 34 & 21.25 & & 2.03 & 1.5 & \\
\hline Apartment /Unit & & 33 & 20.63 & & 4.03 & 4 & \\
\hline Other Commercial Venue & & 8 & 5.00 & & 2.13 & 1 & \\
\hline Nature Reserve/Park & & 7 & 4.38 & & 2.29 & 3 & \\
\hline Bar/Pub & & 5 & 3.13 & & 3.00 & 3 & \\
\hline Cafe/Restaurant & & 5 & 3.13 & & 1.60 & 2 & \\
\hline Other Housing Type & & 5 & 3.13 & & 2.60 & 3 & \\
\hline Car Park & & 3 & 1.88 & & 1.33 & 2 & \\
\hline Petrol Station & & 3 & 1.88 & & 3.67 & 4 & \\
\hline Shopping Mall & & 2 & 1.25 & & 5.00 & 5 & \\
\hline Hotel & & 1 & 0.63 & & 1.00 & 1 & \\
\hline Other (e.g. river, vacant & & 1 & 0.63 & & 2.00 & 2 & \\
\hline Total Incidents & & 160 & 100.00 & & 2.81 & 2 & \\
\hline
\end{tabular}


Table 2

Mean Characteristics of Homes Sold and Rented in Sydney

Panel A. Sales

Sales not within 0.3 miles $\quad$ Sales within 0.3 miles

of murder area and one of a murder and one

Difference

Standard

year before or after

year before or after

Sales price $(\$ 100,000)$

7.335

0.564

6.091

0.327

8.918

5.193

Size of houses (1,000 square feet)

2.84

Number of bedrooms

1.565

Number of bathrooms

0.319

2.291

1.355

0.162

$-1.244 * * \quad[0.060]$

$-0.237 * * \quad[0.004]$

$-3.725 * * \quad[0.408]$

$-0.549 * * \quad[0.009]$

312,013

13,218

[0.006]

Number of observations

Rents not within 0.3 miles

of murder area and one

Rents within 0.3 miles

of a murder and one

Difference

Panel B. Rents

Rental price $(\$ 100)$

year before or after year before or after

$\begin{array}{llll}5.788 & 5.728 & -0.060 & {[0.444]} \\ 0.384 & 0.228 & -0.156^{* * *} & {[0.003]} \\ 9.576 & 5.515 & -4.061^{* * *} & {[0.388]} \\ 2.382 & 1.989 & -0.393^{* * *} & {[0.006]} \\ 1.352 & 1.242 & -0.110^{* * *} & {[0.004]} \\ 0.193 & 0.094 & -0.099^{* * *} & {[0.003]}\end{array}$
452,032 25,185

$\%$ houses

Size of houses $(1,000$ square feet $)$

Number of bedrooms

Number of bathrooms

$\%$ with multiple parking

Number of observations

Notes: Before (after) murder refers to homes sold one year prior (subsequent) to a murder. Standard errors are in square brackets. $* * *, * *, *$ denote statistical significance at the one, five and ten percent level respectively. 0.3 miles are approximately 483 metres. 
Table 3

Sales and Rents One Year Before or After Different Numbers of Murder Incidents

\begin{tabular}{|c|c|c|c|}
\hline$\overline{\text { Samp }}$ & & Sales & Rents \\
\hline Withi & .3 miles of at least one murder incident & 14,461 & 28,170 \\
\hline$"$ & " of one murder incident & 13,218 & 25,196 \\
\hline$"$ & " " of two murder incidents & 964 & 2,380 \\
\hline$"$ & " $"$ of three murder incidents & 269 & 552 \\
\hline " & " $\quad$ of four murder incidents & 10 & 41 \\
\hline$"$ & " $\quad$ of five or more murder incidents & 0 & 1 \\
\hline
\end{tabular}

Notes: 0.3 miles is approximately 483 metres. 
Table 4

Spatial Specification Check of Sales and Rents in Murder Locations

Panel A. Sales

\begin{tabular}{|c|c|c|c|c|c|c|}
\hline $\begin{array}{l}\text { Sample: One year before } \\
\text { murder and within } 0.3 \\
\text { miles of murder }\end{array}$ & Log price & $\%$ houses & $\begin{array}{l}\text { Size of } \\
\text { houses } \\
(1,000 \\
\text { square feet })\end{array}$ & $\begin{array}{l}\text { Number of } \\
\text { bedrooms }\end{array}$ & $\begin{array}{l}\text { Number of } \\
\text { bathrooms }\end{array}$ & $\begin{array}{l}\% \text { with } \\
\text { multiple } \\
\text { parking }\end{array}$ \\
\hline & [1] & [2] & {$[3]$} & [4] & [5] & [6] \\
\hline \multicolumn{7}{|l|}{ Between 0.1 and 0.2 miles } \\
\hline of murder & $-0.052 * *$ & $-0.054 * *$ & $-0.589 * *$ & $-0.123 * * *$ & $-0.054 * *$ & $-0.023 * *$ \\
\hline \multirow{2}{*}{ Within 0.1 miles of murder } & -0.067 & $-0.098 * * *$ & $-0.742 * * *$ & $-0.174 * * *$ & $-0.066 * *$ & $-0.038 * *$ \\
\hline & {$[0.040]$} & {$[0.043]$} & {$[0.276]$} & {$[0.066]$} & {$[0.032]$} & {$[0.018]$} \\
\hline \multirow[t]{2}{*}{ Intercept } & $13.166 * * *$ & $0.243 * * *$ & $1.983 * * *$ & $2.183 * * *$ & $1.317 * * *$ & $0.124 * * *$ \\
\hline & {$[0.093]$} & {$[0.069]$} & {$[0.741]$} & {$[0.191]$} & {$[0.038]$} & {$[0.027]$} \\
\hline Year fixed effects & Yes & Yes & Yes & Yes & Yes & Yes \\
\hline Adjusted $\mathrm{R}^{2}$ & 0.012 & 0.026 & 0.003 & 0.019 & 0.006 & 0.015 \\
\hline Number of observations & 6,011 & 6,011 & 6,011 & 6,011 & 6,011 & 6,011 \\
\hline \multirow[t]{2}{*}{$\begin{array}{l}\text { Sample: One year before } \\
\text { murder and within } 0.2 \\
\text { miles of murder }\end{array}$} & Log price & $\%$ houses & $\begin{array}{l}\text { Size of } \\
\text { houses } \\
(1,000 \\
\text { square feet })\end{array}$ & $\begin{array}{l}\text { Number of } \\
\text { bedrooms }\end{array}$ & $\begin{array}{l}\text { Number of } \\
\text { bathrooms }\end{array}$ & $\begin{array}{l}\% \text { with } \\
\text { multiple } \\
\text { parking }\end{array}$ \\
\hline & [7] & [8] & [9] & {$[10]$} & [11] & {$[12]$} \\
\hline \multirow[t]{2}{*}{ Within 0.1 miles of murder } & -0.012 & -0.042 & -0.153 & -0.052 & -0.012 & -0.015 \\
\hline & {$[0.038]$} & {$[0.027]$} & {$[0.148]$} & {$[0.059]$} & {$[0.032]$} & {$[0.017]$} \\
\hline \multirow[t]{2}{*}{ Intercept } & $13.126 * * *$ & $0.214 * * *$ & $1.148 * * *$ & $2.086 * * *$ & $1.279 * * *$ & $0.121 * * *$ \\
\hline & {$[0.097]$} & {$[0.066]$} & {$[0.380]$} & {$[0.187]$} & {$[0.046]$} & {$[0.012]$} \\
\hline Year fixed effects & Yes & Yes & Yes & Yes & Yes & Yes \\
\hline Adjusted $\mathrm{R}^{2}$ & 0.015 & 0.023 & 0.011 & 0.012 & 0.002 & 0.012 \\
\hline Number of observations & 2,967 & 2,967 & 2,967 & 2,967 & 2,967 & 2,967 \\
\hline
\end{tabular}

\section{Panel B. Rents}

Sample: One year before Log price $\%$ houses
murder and within 0.3 miles of murder

\section{[1]}

Between 0.1 and 0.2 miles of murder

Within 0.1 miles of murder $-0.017$ [0.022]

$-0.038$

[0.026]

Intercept

$6.224 * * *$

[0.042]

Year fixed effects

$$
\text { Yes }
$$

0.054

$\%$ houses

Size of

$\begin{array}{llll}\begin{array}{l}\text { Size of } \\ \text { houses } \\ (1,000\end{array} & \begin{array}{l}\text { Number of } \\ \text { bedrooms }\end{array} & \begin{array}{l}\text { Number of } \\ \text { bathrooms }\end{array} & \begin{array}{l}\% \text { with } \\ \text { multiple } \\ \text { parking }\end{array}\end{array}$
square feet)

Adjusted $\mathrm{R}^{2}$

[2]

[3]

[4]

[5]

[6]

Number of observations

Sample: One year before murder and within 0.2 miles of murder

11,574

$-0.02$

[0.021]

$-0.061 *$

$-0.13$

[0.103]

$-0.072 *$

[0.042]

$-0.083$

$-0.026$

[0.199]

[0.072]

$0.171 * * *$

0.902

1.936 ***

[0.250]

[0.116]

Yes

Yes

0.003

0.006

11,574

11,574

11,574

Size of

Number of

houses

$(1,000$

square feet)

\begin{tabular}{|c|c|c|c|c|c|c|}
\hline & [7] & [8] & [9] & {$[10]$} & [11] & {$[12]$} \\
\hline \multirow[t]{2}{*}{ Within 0.1 miles of murder } & -0.022 & -0.043 & 0.041 & 0.043 & 0.014 & 0.029 \\
\hline & {$[0.025]$} & {$[0.026]$} & {$[0.181]$} & {$[0.065]$} & {$[0.031]$} & {$[0.024]$} \\
\hline \multirow{2}{*}{ Intercept } & $6.211 * * *$ & $0.159 * * *$ & $0.766 * * *$ & $1.86 * * *$ & $1.223 * * *$ & $0.084 * * *$ \\
\hline & {$[0.044]$} & {$[0.054]$} & {$[0.277]$} & {$[0.140]$} & {$[0.030]$} & {$[0.019]$} \\
\hline Year fixed effects & Yes & Yes & Yes & Yes & Yes & Yes \\
\hline Adjusted $\mathrm{R}^{2}$ & 0.061 & 0.017 & 0.002 & 0.029 & 0.003 & 0.002 \\
\hline Number of observations & 5,753 & 5,753 & 5,753 & 5,753 & 5,753 & 5,753 \\
\hline
\end{tabular}

Notes: Clustered standard errors by murder area are in square brackets. $* * *, * *, *$ denote statistical significance at the one, five and ten percent level respectively. 0.3, 0.2 and 0.1 miles are approximately 483, 322 and 161 metres, respectively. 
Table 5

The Effect of Murders on Prices and Rents

\begin{tabular}{|c|c|c|c|c|c|c|c|c|}
\hline \multirow[b]{2}{*}{$\begin{array}{l}\text { Sample: One year before or after murder, with one } \\
\text { month skip after murder. Either full, within } 0.3 \text { or } \\
\text { within } 0.2 \text { mile of murder sample. }\end{array}$} & \multicolumn{4}{|c|}{ Dependent Variable: $\ln$ (price) } & \multicolumn{4}{|c|}{ Dependent Variable: $\ln ($ rent $)$} \\
\hline & $\begin{array}{l}\text { Basic model } \\
\text { (full } \\
\text { sample) }\end{array}$ & $\begin{array}{l}\text { Basic model } \\
(0.3 \text { mile } \\
\text { sample })\end{array}$ & $\begin{array}{l}\text { Basic model } \\
(0.2 \text { mile } \\
\text { sample })\end{array}$ & $\begin{array}{l}\text { Basic model } \\
\text { distance }(0.2 \\
\text { mile sample })\end{array}$ & $\begin{array}{l}\text { Basic model } \\
\text { (full sample) }\end{array}$ & $\begin{array}{l}\text { Basic model } \\
(0.3 \text { mile } \\
\text { sample })\end{array}$ & $\begin{array}{l}\text { Basic model } \\
(0.2 \text { mile } \\
\text { sample })\end{array}$ & $\begin{array}{l}\text { Basic model } \\
\text { distance }(0.2 \\
\text { mile sample })\end{array}$ \\
\hline \multirow{3}{*}{ Between 0.2 and 0.3 miles of murder } & [1] & {$[2]$} & [3] & {$[4]$} & {$[5]$} & [6] & [7] & [8] \\
\hline & -0.012 & & & & 0.004 & & & \\
\hline & {$[0.009]$} & & & & {$[0.007]$} & & & \\
\hline \multirow[t]{2}{*}{ Between 0.1 and 0.2 miles of murder } & -0.017 & 0.003 & & & $-0.016^{*}$ & -0.010 & & \\
\hline & {$[0.015]$} & {$[0.011]$} & & & {$[0.009]$} & {$[0.008]$} & & \\
\hline \multirow[t]{2}{*}{ Within 0.1 miles of murder } & -0.015 & 0.016 & 0.014 & 0.015 & 0.002 & 0.008 & 0.017 & 0.017 \\
\hline & [0.019] & {$[0.020]$} & {$[0.017]$} & {$[0.017]$} & {$[0.016]$} & {$[0.014]$} & {$[0.012]$} & {$[0.012]$} \\
\hline \multirow{2}{*}{ Between 0.2 and 0.3 miles of murder $\times$ after } & 0.006 & -0.016 & & & -0.007 & -0.002 & & \\
\hline & {$[0.008]$} & {$[0.013]$} & & & {$[0.005]$} & {$[0.013]$} & & \\
\hline \multirow[t]{2}{*}{ Between 0.1 and 0.2 miles of murder $\times$ after } & -0.008 & $-0.033 * *$ & $-0.037 * *$ & $-0.037 * *$ & 0.004 & -0.003 & -0.016 & -0.016 \\
\hline & {$[0.009]$} & {$[0.014]$} & {$[0.016]$} & {$[0.016]$} & {$[0.006]$} & {$[0.011]$} & {$[0.016]$} & {$[0.016]$} \\
\hline \multirow[t]{2}{*}{ Within 0.1 miles murder $\times$ after } & -0.021 & $-0.032 *$ & $-0.042 * *$ & -0.012 & 0.004 & 0.001 & -0.012 & -0.021 \\
\hline & {$[0.018]$} & {$[0.018]$} & {$[0.019]$} & {$[0.032]$} & {$[0.012]$} & {$[0.017]$} & {$[0.020]$} & {$[0.036]$} \\
\hline \multirow[t]{2}{*}{ Dist $\leq 0.1$ miles $\times$ after $(0.1$ miles $=1)$} & & & & -0.043 & & & & 0.013 \\
\hline & & & & [0.039] & & & & {$[0.041]$} \\
\hline \multirow[t]{2}{*}{ Intercept } & $13.279 * *$ & $14.957 * *$ & $11.732 * *$ & $11.810^{* *}$ & $5.784 * *$ & $7.027 * *$ & $6.064 * *$ & $6.066^{* *}$ \\
\hline & [0.192] & {$[1.077]$} & [1.968] & [1.982] & {$[0.047]$} & {$[1.001]$} & {$[1.822]$} & {$[1.825]$} \\
\hline Housing characteristics & Yes & Yes & Yes & Yes & Yes & Yes & Yes & Yes \\
\hline Year-quarter fixed effects & Yes & Yes & Yes & Yes & Yes & Yes & Yes & Yes \\
\hline Suburb/murder area linear time trends & Suburb & Murder & Murder & Murder & Suburb & Murder & Murder & Murder \\
\hline Murder area quadratic time trends & No & Yes & Yes & Yes & No & Yes & Yes & Yes \\
\hline Suburb/murder area fixed effects & Suburb & Murder & Murder & Murder & Suburb & Murder & Murder & Murder \\
\hline Clustered standard errors by suburb/murder area & Suburb & Murder & Murder & Murder & Suburb & Murder & Murder & Murder \\
\hline Adjusted $\mathrm{R}^{2}$ & 0.8075 & 0.7732 & 0.8092 & 0.8092 & 0.7405 & 0.6997 & 0.6672 & 0.6672 \\
\hline Number of murder areas & 151 & 151 & 142 & 142 & 151 & 151 & 146 & 146 \\
\hline Number of observations & 243,430 & 12,678 & 6,172 & 6,172 & 350,811 & 27,001 & 11,988 & 11,988 \\
\hline
\end{tabular}

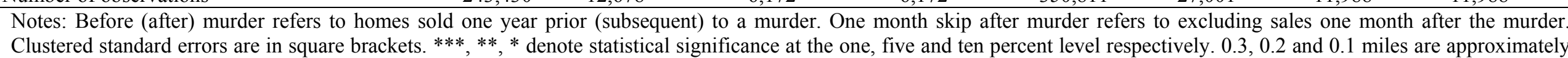
483, 322 and 161 metres, respectively. 
Table 6

The Effect of Murders with High Media Coverage on Prices and Rents

\begin{tabular}{|c|c|c|c|c|c|c|}
\hline \multirow[b]{2}{*}{$\begin{array}{l}\text { Sample: One year before or after } \\
\text { murder, with one month skip after } \\
\text { murder. Either full, within } 0.3 \text { or } \\
\text { within } 0.2 \text { mile of murder sample. }\end{array}$} & \multicolumn{3}{|c|}{ Dependent Variable: $\ln$ (price) } & \multicolumn{3}{|c|}{ Dependent Variable: $\ln (\mathrm{rent})$} \\
\hline & $\begin{array}{l}\text { Media } \\
\text { interaction } \\
\text { (full } \\
\text { sample) }\end{array}$ & $\begin{array}{l}\text { Media } \\
\text { interaction } \\
(0.3 \text { mile } \\
\text { sample })\end{array}$ & $\begin{array}{l}\text { Media } \\
\text { interaction } \\
(0.2 \text { mile } \\
\text { sample })\end{array}$ & $\begin{array}{l}\text { Media } \\
\text { interaction } \\
\text { (full } \\
\text { sample) }\end{array}$ & $\begin{array}{l}\text { Media } \\
\text { interaction } \\
(0.3 \text { mile } \\
\text { sample })\end{array}$ & $\begin{array}{l}\text { Media } \\
\text { interaction } \\
(0.2 \text { mile } \\
\text { sample })\end{array}$ \\
\hline \multirow{3}{*}{$\begin{array}{l}\text { Between } 0.2 \text { and } 0.3 \text { miles of } \\
\text { murder }\end{array}$} & [1] & [2] & [3] & {$[4]$} & [5] & [6] \\
\hline & -0.006 & & & 0.012 & & \\
\hline & {$[0.014]$} & & & {$[0.011]$} & & \\
\hline \multirow{2}{*}{$\begin{array}{l}\text { Between } 0.1 \text { and } 0.2 \text { miles of } \\
\text { murder }\end{array}$} & -0.004 & 0.000 & & -0.014 & $-0.023 * *$ & \\
\hline & {$[0.024]$} & {$[0.020]$} & & {$[0.014]$} & {$[0.010]$} & \\
\hline Within 0.1 miles of murder & $\begin{array}{l}-0.003 \\
{[0.02]}\end{array}$ & $\begin{array}{r}0.001 \\
{[0.020]}\end{array}$ & $\begin{array}{r}0.004 \\
{[0.021]}\end{array}$ & $\begin{array}{r}0.029 \\
{[0.026]}\end{array}$ & $\begin{array}{r}0.010 \\
{[0.025]}\end{array}$ & $\begin{array}{r}0.032 \\
{[0.022]}\end{array}$ \\
\hline \multirow{2}{*}{$\begin{array}{l}\text { Between } 0.2 \text { and } 0.3 \text { miles of } \\
\text { murder } \times \text { after }\end{array}$} & -0.007 & $-0.034 * *$ & & -0.011 & -0.010 & \\
\hline & {$[0.011]$} & [0.013] & & [0.007] & [0.024] & \\
\hline $\begin{array}{l}\text { Between } 0.1 \text { and } 0.2 \text { miles of } \\
\text { murder } \times \text { after }\end{array}$ & $-0.029^{*}$ & -0.025 & $-0.043 * *$ & -0.01 & -0.015 & -0.037 \\
\hline Within 0.1 miles murder $\times$ after & $\begin{array}{r}{[0.015]} \\
-0.028 \\
{[0.022]}\end{array}$ & $\begin{array}{r}{[0.016]} \\
-0.056^{* *} \\
{[0.021]}\end{array}$ & $\begin{array}{r}{[0.018]} \\
-0.048^{* *} \\
{[0.024]}\end{array}$ & $\begin{array}{r}{[0.011]} \\
-0.003 \\
{[0.023]}\end{array}$ & $\begin{array}{r}{[0.018]} \\
-0.012 \\
{[0.033]}\end{array}$ & $\begin{array}{r}{[0.029]} \\
-0.039 \\
{[0.039]}\end{array}$ \\
\hline \multirow{2}{*}{$\begin{array}{l}\text { Between } 0.2 \text { and } 0.3 \text { miles of high } \\
\text { media murder }\end{array}$} & -0.011 & & & -0.015 & & \\
\hline & {$[0.018]$} & & & {$[0.015]$} & & \\
\hline \multirow{2}{*}{$\begin{array}{l}\text { Between } 0.1 \text { and } 0.2 \text { miles of high } \\
\text { media murder }\end{array}$} & -0.024 & 0.005 & 0.213 & -0.004 & 0.024 & 0.551 \\
\hline & {$[0.026]$} & {$[0.023]$} & [2.489] & [0.019] & [0.016] & [1.972] \\
\hline \multirow{2}{*}{$\begin{array}{l}\text { Within } 0.1 \text { miles of high media } \\
\text { murder }\end{array}$} & -0.025 & 0.027 & 0.233 & $-0.053^{*}$ & -0.004 & 0.522 \\
\hline & [0.037] & [0.034] & [2.48] & {$[0.030]$} & {$[0.029]$} & {$[1.975]$} \\
\hline \multirow{2}{*}{$\begin{array}{l}\text { Between } 0.2 \text { and } 0.3 \text { miles of high } \\
\text { media murder } \times \text { after }\end{array}$} & 0.026 & 0.036 & & 0.007 & 0.021 & \\
\hline & {$[0.016]$} & {$[0.025]$} & & {$[0.008]$} & {$[0.026]$} & \\
\hline \multirow[t]{2}{*}{$\begin{array}{l}\text { Between } 0.1 \text { and } 0.2 \text { miles of high } \\
\text { media murder } \times \text { after }\end{array}$} & $0.043 *$ & 0.016 & 0.011 & $0.029 * *$ & 0.029 & 0.051 \\
\hline & {$[0.026]$} & {$[0.020]$} & {$[0.027]$} & {$[0.014]$} & {$[0.019]$} & {$[0.042]$} \\
\hline $\begin{array}{l}\text { Within } 0.1 \text { miles of high media } \\
\text { murder } \times \text { after }\end{array}$ & 0.012 & 8 & 0.012 & 0.013 & 0.029 & 0. \\
\hline Intercept & $\begin{array}{r}{[0.034]} \\
13.28^{* *} \\
{[0.191]}\end{array}$ & $\begin{array}{r}{[0.036]} \\
14.786^{* *} \\
{[1.084]}\end{array}$ & $\begin{array}{r}{[0.036]} \\
11.492 * * \\
{[0.983]}\end{array}$ & $\begin{array}{r}{[0.025]} \\
5.784^{* *} \\
{[0.047]}\end{array}$ & $\begin{array}{r}{[0.036]} \\
6.921 * * \\
{[1.052]}\end{array}$ & $\begin{array}{r}{[0.029]} \\
5.547^{* *} \\
{[0.15]}\end{array}$ \\
\hline $\mathrm{H}$ & Yes & Yes & Yes & Yes & Yes & Yes \\
\hline Year-quarter fixed effects & Yes & Yes & Yes & Yes & Yes & Yes \\
\hline $\begin{array}{l}\text { Suburb/murder area linear time } \\
\text { trends }\end{array}$ & Suburb & Murder & Murder & Suburb & Murder & Murder \\
\hline $\begin{array}{l}\text { Murder area quadratic time trends } \\
\text { Suburb/murder area fixed effects }\end{array}$ & $\begin{array}{l}\text { No } \\
\text { Suburb }\end{array}$ & $\begin{array}{l}\text { Yes } \\
\text { Murder }\end{array}$ & $\begin{array}{l}\text { Yes } \\
\text { Murder }\end{array}$ & $\begin{array}{l}\text { No } \\
\text { Suburb }\end{array}$ & $\begin{array}{l}\text { Yes } \\
\text { Murder }\end{array}$ & $\begin{array}{l}\text { Yes } \\
\text { Murder }\end{array}$ \\
\hline $\begin{array}{l}\text { Clustered standard errors by } \\
\text { suburb/murder area }\end{array}$ & Suburb & Murder & Murder & Suburb & Murder & Murder \\
\hline Adjusted $\mathrm{R}^{2}$ & 0.8075 & 0.7733 & 0.8092 & 0.7405 & 0.6999 & 0.6674 \\
\hline & 151 & & 142 & 151 & 151 & 146 \\
\hline Numb & 243,430 & 12,678 & 6,172 & 350,811 & 27001 & 11,988 \\
\hline
\end{tabular}

Notes: Before (after) murder refers to homes sold one year prior (subsequent) to a murder. One month skip after murder refers to excluding sales one month after the murder. Clustered standard errors are in square brackets. ${ }^{* * *}, * *,{ }^{*}$ denote statistical significance at the one, five and ten percent level respectively. $0.3,0.2$ and 0.1 miles are approximately 483 , 322 and 161 metres, respectively. 
Table 7

The Effect of Murders on Prices and Rents Stratified by Past Assault Rate

\begin{tabular}{|c|c|c|c|}
\hline \multicolumn{4}{|l|}{ Panel A. Prices } \\
\hline \multirow[b]{2}{*}{$\begin{array}{l}\text { Sample: Within } 0.3 \text { miles of murder, one year } \\
\text { before or after murder with one month skip after } \\
\text { murder }\end{array}$} & \multicolumn{3}{|c|}{ Dependent Variable: $\ln$ (price) } \\
\hline & Low assault areas & $\begin{array}{l}\text { Medium assault } \\
\text { areas }\end{array}$ & High assault areas \\
\hline \multirow{3}{*}{ Between 0.1 and 0.2 miles of murder } & {$[1]$} & {$[2]$} & {$[3]$} \\
\hline & 0.001 & 0.023 & -0.012 \\
\hline & {$[0.012]$} & {$[0.014]$} & {$[0.030]$} \\
\hline \multirow{2}{*}{ Within 0.1 miles of murder } & 0.010 & 0.004 & 0.008 \\
\hline & {$[0.024]$} & {$[0.018]$} & [0.047] \\
\hline \multirow[t]{2}{*}{ Between 0.2 and 0.3 miles of murder $\times$ after } & $-0.039 * *$ & -0.014 & -0.016 \\
\hline & {$[0.014]$} & {$[0.024]$} & {$[0.029]$} \\
\hline \multirow[t]{2}{*}{ Between 0.1 and 0.2 miles of murder $\times$ after } & -0.009 & $-0.024 *$ & -0.016 \\
\hline & {$[0.012]$} & {$[0.012]$} & {$[0.020]$} \\
\hline \multirow[t]{2}{*}{ Within 0.1 miles murder $\times$ after } & -0.050 & -0.013 & -0.042 \\
\hline & {$[0.031]$} & {$[0.026]$} & {$[0.037]$} \\
\hline \multirow[t]{2}{*}{ Intercept } & $15.512 * *$ & $15.256^{* *}$ & $10.361 * *$ \\
\hline & {$[2.331]$} & {$[1.707]$} & {$[1.758]$} \\
\hline Housing characteristics & Yes & Yes & Yes \\
\hline Year-quarter fixed effects & Yes & Yes & Yes \\
\hline Murder area linear time trends & Yes & Yes & Yes \\
\hline Murder area quadratic time trends & Yes & Yes & Yes \\
\hline Murder area fixed effects & Yes & Yes & Yes \\
\hline Clustered standard errors by murder area & Yes & Yes & Yes \\
\hline Adjusted $\mathrm{R}^{2}$ & 0.8235 & 0.8758 & 0.6766 \\
\hline Number of murder areas & 51 & 50 & 50 \\
\hline Number of observations & 4,743 & 3,268 & 4,667 \\
\hline
\end{tabular}

\section{Panel B. Rents}

Dependent Variable: $\ln ($ rent $)$

\begin{tabular}{llll}
\hline $\begin{array}{l}\text { Sample: Within } 0.3 \text { miles of murder, one year } \\
\text { before or after murder with one month skip after } \\
\text { murder }\end{array}$ & $\begin{array}{l}\text { Low assault areas } \\
\text { areas }\end{array}$ & $\begin{array}{l}\text { Medium assault } \\
\text { assault areas }\end{array}$ & High assal \\
\hline
\end{tabular}

murder

Between 0.1 and 0.2 miles of murder

\begin{tabular}{ccc}
{$[1]$} & {$[2]$} & {$[3]$} \\
-0.008 & -0.006 & -0.033 \\
{$[0.014]$} & {$[0.009]$} & {$[0.021]$} \\
0.008 & -0.004 & -0.031 \\
{$[0.018]$} & {$[0.012]$} & {$[0.023]$} \\
-0.010 & -0.002 & -0.001 \\
{$[0.018]$} & {$[0.008]$} & {$[0.009]$} \\
0.006 & -0.002 & 0.012 \\
{$[0.014]$} & {$[0.010]$} & {$[0.007]$} \\
-0.010 & 0.002 & 0.015 \\
{$[0.023]$} & {$[0.014]$} & {$[0.023]$} \\
$4.932 * *$ & $3.078^{* *}$ & $6.569^{* *}$ \\
{$[0.521]$} & {$[0.499]$} & {$[0.407]$} \\
Yes & Yes & Yes \\
Yes & Yes & Yes \\
Yes & Yes & Yes \\
Yes & Yes & Yes \\
Yes & Yes & Yes \\
Yes & Yes & Yes \\
0.7433 & 0.7740 & 0.6749 \\
48 & 51 & 49 \\
479 & 11,247 & 17,393 \\
\hline
\end{tabular}

Number of observations

13,479

11,247

17,393

Notes: Before (after) murder refers to homes sold one year prior (subsequent) to a murder. One month skip after murder refers to excluding sales one month after the murder. The sample is stratified into three groups based on the past five year average assault rate in the murder area's local government area. Clustered standard errors are in square brackets. $* * *, * *, *$ denote statistical significance at the one, five and ten percent level respectively. $0.3,0.2$ and 0.1 miles are approximately 483, 322 and 161 metres, respectively. 
Table 8

False Murder Dates One Year Prior to Murder

\begin{tabular}{|c|c|c|c|c|}
\hline \multirow{2}{*}{$\begin{array}{l}\text { Sample: Within } 0.2 \text { or } 0.3 \text { miles of murder, one } \\
\text { year before or after false murder date with one } \\
\text { month skip after false murder date. }\end{array}$} & \multicolumn{2}{|c|}{ Dependent Variable: $\ln$ (price) } & \multicolumn{2}{|c|}{ Dependent Variable: $\ln ($ rent $)$} \\
\hline & $\begin{array}{l}\text { Basic model } \\
(0.3 \text { mile } \\
\text { sample })\end{array}$ & $\begin{array}{l}\text { Basic model } \\
(0.2 \text { mile } \\
\text { sample })\end{array}$ & $\begin{array}{l}\text { Basic model } \\
(0.3 \text { mile } \\
\text { sample })\end{array}$ & $\begin{array}{l}\text { Basic model } \\
(0.2 \text { mile } \\
\text { sample })\end{array}$ \\
\hline \multirow{3}{*}{ Within 0.1 and 0.2 miles of murder } & {$[1]$} & {$[2]$} & {$[3]$} & [4] \\
\hline & -0.005 & & $-0.017 *$ & \\
\hline & [0.011] & & {$[0.009]$} & \\
\hline \multirow[t]{2}{*}{ Within 0.1 miles of murder } & 0.010 & 0.011 & -0.013 & 0.007 \\
\hline & [0.021] & [0.019] & {$[0.011]$} & {$[0.009]$} \\
\hline \multirow[t]{2}{*}{ Within 0.2 and 0.3 miles of murder $\times$ after } & -0.015 & & -0.016 & \\
\hline & [0.012] & & {$[0.011]$} & \\
\hline \multirow[t]{2}{*}{ Within 0.1 and 0.2 miles of murder $\times$ after } & -0.020 & -0.015 & -0.004 & -0.004 \\
\hline & [0.013] & {$[0.020]$} & {$[0.008]$} & {$[0.012]$} \\
\hline \multirow[t]{2}{*}{ Within 0.1 miles murder $\times$ after } & -0.021 & -0.007 & 0.001 & 0.001 \\
\hline & {$[0.017]$} & [0.019] & {$[0.010]$} & {$[0.013]$} \\
\hline \multirow[t]{2}{*}{ Intercept } & $11.360 * *$ & $13.773 * *$ & $6.054 * *$ & $3.821 * *$ \\
\hline & {$[2.011]$} & {$[2.302]$} & {$[1.108]$} & {$[1.554]$} \\
\hline Housing characteristics & Yes & Yes & Yes & Yes \\
\hline Year-quarter fixed effects & Yes & Yes & Yes & Yes \\
\hline Murder area linear time trends & Yes & Yes & Yes & Yes \\
\hline Murder area quadratic time trends & Yes & Yes & Yes & Yes \\
\hline Murder area fixed effects & Yes & Yes & Yes & Yes \\
\hline Clustered standard errors by murder location & Yes & Yes & Yes & Yes \\
\hline Adjusted $\mathrm{R}^{2}$ & 0.7952 & 0.8100 & 0.7268 & 0.7098 \\
\hline Number of murder areas & 148 & 141 & 149 & 142 \\
\hline Number of observations & 12,958 & 6,336 & 27,790 & 11,930 \\
\hline
\end{tabular}

Notes: Before (after) murder refers to homes sold or for rent one year prior (subsequent) to the false murder date. The false murder date is one year prior to the actual murder. One month skip after false murder refers to removing sales (rents) one month after the false murder date. Clustered standard errors are in square brackets. $* * *, * *, *$ denote statistical significance at the one, five and ten percent level respectively. $0.3,0.2$ and 0.1 miles are approximately 483, 322 and 161 metres, respectively. 
Table 9

Price and Rents using Two Years Before and After Murder

\begin{tabular}{|c|c|c|c|c|}
\hline \multirow{2}{*}{$\begin{array}{l}\text { Sample: Within } 0.2 \text { or } 0.3 \text { miles of murder, two } \\
\text { years before or after murder with one month } \\
\text { skip after murder }\end{array}$} & \multicolumn{2}{|c|}{ Dependent Variable: $\ln ($ price $)$} & \multicolumn{2}{|c|}{ Dependent Variable: $\ln ($ rent $)$} \\
\hline & $\begin{array}{l}\text { Basic model } \\
(0.3 \text { mile } \\
\text { sample }) \\
\end{array}$ & $\begin{array}{l}\text { Basic model } \\
(0.2 \text { mile } \\
\text { sample }) \\
\end{array}$ & $\begin{array}{l}\text { Basic model } \\
(0.3 \text { mile } \\
\text { sample })\end{array}$ & $\begin{array}{l}\text { Basic model } \\
(0.2 \text { mile } \\
\text { sample }) \\
\end{array}$ \\
\hline \multirow{3}{*}{ Within 0.1 and 0.2 miles of murder } & {$[1]$} & {$[2]$} & {$[3]$} & [4] \\
\hline & -0.007 & & $-0.017 *$ & \\
\hline & {$[0.012]$} & & {$[0.009]$} & \\
\hline \multirow[t]{2}{*}{ Within 0.1 miles of murder } & 0.014 & 0.014 & -0.013 & 0.010 \\
\hline & {$[0.021]$} & {$[0.022]$} & {$[0.011]$} & {$[0.008]$} \\
\hline \multirow[t]{2}{*}{ Within 0.2 and 0.3 miles of murder $\times$ after } & 0.005 & & -0.016 & \\
\hline & {$[0.012]$} & & {$[0.011]$} & \\
\hline \multirow[t]{2}{*}{ Within 0.1 and 0.2 miles of murder $\times$ after } & -0.006 & -0.018 & -0.004 & -0.006 \\
\hline & {$[0.015]$} & {$[0.015]$} & {$[0.008]$} & {$[0.011]$} \\
\hline \multirow[t]{2}{*}{ Within 0.1 miles of murder $\times$ after } & -0.021 & $-0.029^{*}$ & 0.001 & -0.004 \\
\hline & {$[0.015]$} & {$[0.015]$} & {$[0.010]$} & {$[0.015]$} \\
\hline \multirow[t]{2}{*}{ Intercept } & $9.983 * *$ & $13.668 * *$ & $6.054 * *$ & $4.685^{* *}$ \\
\hline & {$[0.695]$} & {$[1.282]$} & {$[1.108]$} & {$[0.494]$} \\
\hline Housing characteristics & Yes & Yes & Yes & Yes \\
\hline Year-quarter fixed effects & Yes & Yes & Yes & Yes \\
\hline Murder area linear time trends & Yes & Yes & Yes & Yes \\
\hline Murder area quadratic time trends & Yes & Yes & Yes & Yes \\
\hline Murder area fixed effects & Yes & Yes & Yes & Yes \\
\hline Clustered standard errors by murder area & Yes & Yes & Yes & Yes \\
\hline Adjusted $\mathrm{R}^{2}$ & 0.7700 & 0.8093 & 0.7268 & 0.7064 \\
\hline Number of murder areas & 147 & 140 & 149 & 141 \\
\hline Number of observations & 22,016 & 10,651 & 27,790 & 20,694 \\
\hline
\end{tabular}

Notes: Before (after) murder refers to homes sold two years prior (subsequent) to a murder. One month skip after murder refers to excluding sales (rents) one month after the murder. Clustered standard errors are in square brackets. $* * *, * *, *$ denote statistical significance at the one, five and ten percent level respectively. $0.3,0.2$ and 0.1 miles are approximately 483, 322 and 161 metres, respectively. 
Appendix A

Global Comparison of Yearly Intentional Homicides per 100,000

\begin{tabular}{lcccccc}
\hline Year & Sydney & Australia & Canada & Japan & $\begin{array}{c}\text { United Kingdom } \\
\text { (England and Wales) }\end{array}$ & USA \\
2003 & 1.62 & 1.52 & 1.54 & 0.50 & 1.71 & 5.57 \\
2004 & 1.34 & 1.31 & 1.72 & 0.50 & 1.64 & 5.39 \\
2005 & 1.14 & 1.27 & 1.84 & 0.46 & 1.44 & 5.53 \\
2006 & 1.55 & 1.36 & 1.71 & 0.44 & 1.41 & 5.57 \\
2007 & 1.19 & 1.22 & 1.64 & 0.40 & 1.45 & 5.48 \\
2008 & 1.02 & 1.23 & 1.67 & 0.45 & 1.19 & 5.22 \\
Average & 1.31 & 1.32 & 1.69 & 0.46 & 1.48 & 5.46 \\
\hline
\end{tabular}


Appendix B

Murders Matched to BOCSAR Statistics

\begin{tabular}{lccccc}
\hline Year & $\begin{array}{c}\text { Murders reported in } \\
\text { BOCSAR statistics }\end{array}$ & $\begin{array}{c}\text { Murders matched to } \\
\text { news media }\end{array}$ & \% matched & $\begin{array}{c}\text { Number geocoded } \\
\text { with accuracy }\end{array}$ & \% geocoded \\
2003 & 60 & 50 & 83.33 & 42 & 70.00 \\
2004 & 50 & 37 & 74.00 & 31 & 62.00 \\
2005 & 43 & 37 & 86.05 & 30 & 69.77 \\
2006 & 59 & 53 & 89.83 & 47 & 79.66 \\
2007 & 46 & 36 & 78.26 & 30 & 70.22 \\
2008 & 40 & 37 & 92.50 & 28 & 80.00 \\
2009 & 50 & 45 & 90.00 & 40 & 65.79 \\
2010 & 38 & 32 & 84.21 & 25 & 70.73 \\
Total & 386 & 327 & 84.72 & 273 & \\
\hline
\end{tabular}

Notes: Statistics count number of murder victims. 'With accuracy' refers to murder incidents where the exact location is found from court decisions, newspaper or police media releases or where a 0.1 miles radius covers the entire street where a murder incident is reported to have occurred. 
Appendix C

List of Housing Characteristic Variables

\begin{tabular}{|c|c|}
\hline Variable & Description \\
\hline Beds & Number of beds \\
\hline Baths & Number of bathrooms \\
\hline Multiple Parking & 1 if home has two or more parking spots, 0 otherwise \\
\hline Area size & Land area size of houses (square metres) \\
\hline Street type dummies & 1 if a certain street type (e.g. avenue, highway, lane, street, road, etc.), 0 otherwise \\
\hline Housing type dummies & $\begin{array}{l}1 \text { if a certain housing type (e.g. apartment, house, semi, studio, townhouse, villa, } \\
\text { etc.), } 0 \text { otherwise }\end{array}$ \\
\hline HasAirConditioning & 1 if home has air conditioning, 0 otherwise \\
\hline HasAlarm & 1 if home has alarm system, 0 otherwise \\
\hline HasBalcony & 1 if home has balcony, 0 otherwise \\
\hline HasBarbeque & 1 if home has barbeque, 0 otherwise \\
\hline HasBeenRenovated & 1 if home has been renovated, 0 otherwise \\
\hline HasBilliardRoom & 1 if home has billiard room, 0 otherwise \\
\hline HasCourtyard & 1 if home has courtyard, 0 otherwise \\
\hline HasEnsuite & 1 if home has ensuite, 0 otherwise \\
\hline HasFamilyRoom & 1 if home has family room, 0 otherwise \\
\hline HasFireplace & 1 if home has fire place, 0 otherwise \\
\hline HasGarage & 1 if home has garage, 0 otherwise \\
\hline HasHeating & 1 if home has heating, 0 otherwise \\
\hline HasInternalLaundry & 1 if home has internal laundry, 0 otherwise \\
\hline HasLockUpGarage & 1 if home has lock up garage, 0 otherwise \\
\hline HasPolishedTimberFloor & 1 if home has polished timber floors, 0 otherwise \\
\hline HasPool & 1 if home has swimming pool, 0 otherwise \\
\hline HasRumpusRoom & 1 if home has rumpus room, 0 otherwise \\
\hline HasSauna & 1 if home has sauna, 0 otherwise \\
\hline HasSeparateDining & 1 if home has separate dining room, 0 otherwise \\
\hline HasSpa & 1 if home has spa, 0 otherwise \\
\hline HasStudy & 1 if home has study room, 0 otherwise \\
\hline HasSunroom & 1 if home has sunroom, 0 otherwise \\
\hline HasTennisCourt & 1 if home has tennis court, 0 otherwise \\
\hline HasWalkInWardrobe & 1 if home has walk in wardrobe, 0 otherwise \\
\hline View dummies & $\begin{array}{l}1 \text { if home has a certain view (e.g. bush, city, district, harbour, ocean, park, river, etc.), } \\
0 \text { otherwise }\end{array}$ \\
\hline
\end{tabular}


Appendix D

Selection Criteria Statistics for Hedonic Price Models

\section{Panel A. Full Sample}

Model Variables

1 Beds, baths, multiple parking, area size,

1 street type dummies, housing type dummies

$2 \quad$ Model 1 plus suburb fixed effects

3 Model 2 plus year/quarter fixed effects and

suburb linear time trends

4 Model 3 plus all other housing characteristics

\section{Panel B. 0.3 Mile Sample}

\section{Model Variables}

1 Beds, baths, multiple parking, area size,

street type dummies, housing type dummies

2 Model 1 plus murder area fixed effects

3 Model 2 plus year/quarter fixed effects and

3 murder area linear/quadratic time trends

$4 \quad$ Model 3 plus all other housing

$4 \quad$ characteristics

Panel C. 0.2 Mile Sample

\section{Model Variables}

1 Beds, baths, multiple parking, area size,

1 street type dummies, housing type dummies

$2 \quad$ Model 1 plus murder area fixed effects

3 Model 2 plus year/quarter fixed effects and

3 murder area linear/quadratic time trends

$4 \quad$ Model 3 plus all other housing characteristics

\begin{tabular}{|c|c|c|c|}
\hline Adjusted $\mathrm{R}^{2}$ & AIC & $\mathrm{BIC}$ & PRESS \\
\hline 0.3790 & $-138,282$ & $-379,161$ & 50,141 \\
\hline 0.8005 & $-411,210$ & $-652,085$ & 19,310 \\
\hline 0.8043 & $-415,136$ & $-656,000$ & 18,130 \\
\hline 0.8074 & $-418,989$ & $-659,852$ & 17,662 \\
\hline Adjusted $\mathrm{R}^{2}$ & AIC & $\mathrm{BIC}$ & PRESS \\
\hline 0.3550 & $-8,169$ & $-20,737$ & 2,412 \\
\hline 0.7613 & $-20,514$ & $-33,076$ & 902 \\
\hline 0.7667 & $-20,630$ & $-33,176$ & 892 \\
\hline 0.7731 & $-20,807$ & $-33,326$ & 961 \\
\hline Adjusted $\mathrm{R}^{2}$ & AIC & $\mathrm{BIC}$ & PRESS \\
\hline 0.3864 & $-4,538$ & $-10,664$ & 1,086 \\
\hline 0.8013 & $-11,306$ & $-17,422$ & 354 \\
\hline 0.8066 & $-11,316$ & $-17,404$ & 352 \\
\hline 0.8090 & $-11,243$ & $-17,281$ & 660 \\
\hline
\end{tabular}


Appendix E

The Effect of Murders on Prices Extra Tests

Sample: Full sample

$[1]$

Between 0.2 and 0.3 miles of murder

Between 0.1 and 0.2 miles of murder

$4.878^{* *}$

[0.29]

Dependent Variable: $\ln$ (price)

Within 0.1 miles of murder

$4.864 * *$

[2]

$-0.059 * *$

[3]

[0.02]

[0.289]

$-0.072 * *$

$3.362 * *$

[0.236]

$4.873 * *$

[0.014]

$3.351 * *$

[0.233]

[0.309]

$-0.066^{*}$

$3.363 * *$

[0.036]

[0.249]

$-0.004$

$-0.004$

$-0.015$

[0.017]

$-0.019$

$-0.022$

[0.014]

$-0.034 * *$

[4]

$-0.019$

$-0.051^{* *}$

[0.018]

[0.017]

[0.022]

$-0.053 * *$

$-0.045^{* *}$

[0.021]

$14.457 * *$

$14.604 * *$

[0.018]

[0.071]

Housing characteristics

Year-quarter fixed effects

Murder area linear time trends

Yes

Yes

[0.072]

Yes

Yes

Yes

Yes

Yes

Murder area quadratic time trends

Murder area fixed effects

Suburb area fixed effects

Clustered standard errors by murder area

Adjusted $\mathrm{R}^{2}$

Yes

No

Yes

0.4534

Number of murder areas

152

243,430

$13.403 * *$

$0.288 * *$

[0.022]

$0.278 * *$

[0.014]

$0.289 * *$

[0.032]

$-0.010$

[0.013]

$-0.030^{*}$

[0.016]

$-0.041 * *$

[0.017]

$13.327 * *$

[0.041]

[0.041]

Yes

Yes

Yes Yes

Yes Yes

No $\quad$ Yes $\quad$ No

Yes Yes Yes

$\begin{array}{ccc}\text { No } & \text { Yes } & \text { Yes } \\ \text { Yes } & \text { Yes } & \text { Yes }\end{array}$

0.4535

152

0.8069

152

0.8069

152

Number of observations

243,430

243,430

243,430

Notes: Before (after) murder refers to homes sold one year prior (subsequent) to a murder. One month skip after murder refers to excluding sales one month after the murder. Clustered standard errors are in square brackets. **, * denotes statistical significant at the five and ten percent level respectively. $0.3,0.2$ and 0.1 miles are approximately 483, 322 and 161 metres, respectively. 